\title{
PROBLEMATIC FIELD OF COMMUNICATIVE PRACTICES UNDER GLOBALIZATION: LINGUISTIC ASPECT
}

\author{
O CAMPO PROBLEMÁTICO DAS PRÁTICAS DE COMUNICAÇÃO NO CONTEXTO \\ DA GLOBALIZAÇÃO: O ASPETO LINGUÍSTICO
}

\author{
ASPECTOS LINGÜISTICOS DE ESFERA PROBLEMATICA DE PRACTICAS \\ COMUNICATIVAS EN ÉPOCA DE GLOBALIZACION
}

\author{
Svetlana K. BONDYREVA ${ }^{1}$ \\ Alexander V. NIKITIN ${ }^{2}$ \\ Elizaveta P. SAVRUTSKAYA ${ }^{3}$ \\ Sergey V. USTINKIN ${ }^{4}$
}

\begin{abstract}
The article examines the features of modern communication that are greatly influenced by globalization and new information communication technologies. Against this background the virtualization of communicative space accelerated in modern civilization. The role of language in the system of culture codes at the present stage of globalization was analysed. It is argued that accumulation and reproduction of socio-cultural experience, implementation of spiritual and moral continuity, and preservation of the defining signs of ethno-cultural identity are associated with the increasing role of language in the execution of these processes, and in the preservation and reproduction of the specific nature of ethnic cultures.
\end{abstract}

KEYWORDS: Mixed objective-virtual reality. Information communication technology. Culture code. Socio-cultural continuity. Civilization. Digitalization. Language. National culture.

RESUMO: $O$ artigo examina as características dos processos contemporâneos de comunicação, altamente expostos à globalização e as novas tecnologias de informação e comunicação, através das quais a virtualização do espaço de comunicação da civilização moderna se acelera; está a ser analisado o papel de linguagem no sistema de códigos culturais na fase atual da globalização; prova-se que existe uma ligação entre a acumulação e reprodução da experiência sociocultural, a realização de continuidade espiritual e moral e preservação dos atributos de identidade etnocultural, e o papel crescente da linguagem na

${ }^{1}$ Moscow Psychological and Social University (MPSU), Moscow - Russian Federation. Professor of the Department of Educational Psychology and Pedagogy. Doctor of Psychological Sciences. ORCID: http://orcid.org/0000-0001-5098-9222. E-mail: elyagalimowa@yandex.ru

2 Linguistic University of Nizhny Novgorod (LUNN), Nizhny Novgorod - Russian Federation. Head of the Department of Philosophy, Sociology and Theory of Social Communication. E-mail: kirill-lena@mail.ru

${ }^{3}$ Linguistic University of Nizhny Novgorod (LUNN), Nizhny Novgorod - Russian Federation. Professor of the Department of Philosophy, Sociology and Theory of Social Communication. Doctor of Philosophy. ORCID: http://orcid.org/0000-0002-1901-6737. E-mail: savrutsk@lunn.ru

${ }^{4}$ Linguistic University of Nizhny Novgorod (LUNN), Nizhny Novgorod - Russian Federation. Professor of the Department of Philosophy, Sociology and Theory of Social Communication. ORCID: http://orcid.org/0000-00031481-3208. E-mail: sv.ustinkin@gmail.com 
implementação destes processos de preservação e reprodução das características específicas de culturas nacionais.

PALAVRAS-CHAVE: Realidade virtual-objetiva mista. Tecnologia de informação e comunicação. Código de cultura. Continuidade sociocultural. Civilização. Digitalização. Lingua. Cultura nacional.

RESUMEN: Aqui se analizan los rasgos de comunicación moderna que estan muy afectados por la globalización y tecnologías nuevas de información y comunicación. Las tecnologías acceleran la virtualización del espacio comunicativo de la civilización moderna. Se también el papel del idioma en el sistema de códigos culturales en la fase moderna de globalización. Se muestra que la acumulación y reproducción de experiencias socioculturales, implementación de continuidad moral y espiritual y preservación de características determinantes de identidad cultural étnica se vinculan al papel creciente del idioma en el transcurso de estos procesos y en la preservación y reproducción de la esencia distinta de culturas étnicas.

PALABRAS CLAVE: Realidad objetiva virtual mezclada. Tecnología de información y comunicación. Código cultural. Continuidad sociocultural. Civilización. Digitalización. Idioma. Cultura nacional.

\section{Introduction}

Due to circumstances that have fundamentally changed the content and direction of socio-cultural processes in the modern world, the problems of communication are generating considerable interest in terms of the modern philosophical narrative. The explanation for this phenomenon lies in the sphere of the specific civilizational features of the modern stage of social development. These features have a major impact on the transformation of communication processes. The types and forms of modern communications are certainly multivarious and their development may take many directions. Hence modern communications need systematization and identification of their dominant features to accumulate a methodological basis for studying them and develop social mechanisms for ensuring the orderliness of the evolving relations between people.

In the context of globalization, information communication technologies establish new rules for assessing changes in the modern communicative space where peoples encounter each other. These changes require a new civilizational paradigm that takes on board the peculiarities of the new digital world, the speed of social development, and the transformation of culture codes, all contributing to escalatory contradictions at the global and national levels. The virtual communication in the space of mixed objective-virtual reality testifies to the emergence of a new phenomenon of socio-cultural reality, determined by the development of digital 
technologies functionally aimed at modifying communication processes (MAKEYEV, 2017).

The article aims to substantiate the standpoint that the accumulation and reproduction of socio-cultural experience, the implementation of spiritual and moral continuity and the preservation of the defining features of ethno-cultural identity are associated with the increasing role of language in the implementation of these processes.

The aspect of research is the linguistic side of the problematic field of communicative practices in the context of globalization.

\section{Methods}

To examine the stated problem, we used theoretical analysis, abstraction, the systemic method, the structural-functional method, them axiomatic method, deduction and induction, and the ascent from the abstract to the concrete.

\section{Results}

The study showed that the accumulation and reproduction of socio-cultural experience, the implementation of spiritual and moral continuity and the preservation of the defining characteristics of ethno-cultural identity are associated with the increasing role of language in the implementation of these processes.

\section{Discussion}

Studies of the transformation of modern types and forms of social communication under civilizational changes of the socio-cultural environment and information communication technology research in the digital community help find and develop mechanisms for human adaptation to the conditions of the emerging world order and the communication processes of the forthcoming post-globalization stage.

The most notable contribution to the communication theory (communication science) was made by US sociologists, such as Alvin Toffler, and European philosophers and sociologists, primarily from Germany and France. The development of the modern philosophical and sociological theory of social communication is associated primarily with the names of Jürgen Habermas (the theory of communicative action), Karl-Otto Apel and Niklas Luhmann. 
In particular, Habermas (2000) considered the socio-cultural conditions of social communication as a fragment of the human lifeworld. The philosopher believes that the context of communication processes is a condition and resource base for actions 'focused on achieving mutual understanding' and consensus. The relief of conflicts is predicated upon the degree of stability of social, primarily moral, precepts that regulate relations between people. The philosopher emphasized that a person exhibits communicative behaviour and performs social roles within a certain system of norms, due to which there emerges 'the world of legitimately ordered interpersonal relations'. Outside the field of norms, a person is also outside the system of relations that ensure social existence. According to Habermas, moral normativity was historically formed as a condition of sociality, as a factor of culture, and as a fragment of the human lifeworld, regulating communication processes between people. Fundamentally, 'the normatively integrated fabric of social relations is moral in and of itself'. Violating mandatory moral norms produces conflicts and deviant behaviour.

In his article Concept of Language Politeness and Building Character Education, Umbar (2019) points to the aggravating problems associated with the fact that contemporary education pays critically insufficient attention to character building, forming of the moral core, and character degradation, manifested in the phenomenon of bad linguistic manners of students.

A significant contribution to the development of the general theory of social communication was made by Karl-Otto Apel, who, in addition to moral problems, included the recognition of the dual role of language (an information transmitter and a communication organizer) in the problematic field of social communication (APEL, 1976).

The Jordanian researcher Abuarqoub (2019) examined the capacity of language in achieving mutual understanding and agreement in his article Language Barriers to Effective Communication. In his other publication Non-Verbal Barriers to Effective Intercultural Communication, co-authored with the Emirati researcher Alzerkhan, the authors conclude that misinterpretation of non-verbal messages and signals arise from the sender and the receiver's misunderstanding of each other's language and culture (ABUARQOUB; ALSERHAN, 2019).

The famous Sapir-Whorf hypothesis is certainly relevant in terms of studying the connection between moral norms and language models in their complex impact on the communicative behaviour of people. Since there can be historically established links between language, culture, and norms of behaviour, the language may suggest the paths of thinking that influence the norms and trends of behaviour. In this regard, Whorf (1939, p. 197-198) wrote that "it is not so much in these special uses of language as in its constant ways of arranging data 
and its most ordinary everyday analysis of phenomena that we need to recognize the influence it has on other activities, cultural and personal".

Given the profound changes in social and virtual reality, the problematic field of modern civilization contributes to the emergence of many independent systems, numerous subcultures that erode what Edward Sapir called the 'formal completeness' of each language. As a result, the meanings transmitted through the language alter and, consequently, the understanding of the historically accumulated social experience, recorded and realized by linguistic means in the communicative practices, alters, too. In this context, the culture-forming and culture-preserving role of language becomes more and more obvious for language acts as 'a guide to social reality' and a mechanism for connecting eras and generations.

In Russian philosophical tradition, Pavel Florensky, Gustav Shpet, Alexander Potebnja, Pavel Novgorodtsev and other representatives of Russian philosophical and culturological schools addressed the problems of social communication and suggested methodologically important approaches to understanding the features of cultural and communicative spheres of society. Thus, Pavel Florensky wrote about Catholic and Protestant verbal cultures. Considering the hermeneutic model of communication, Gustav Shpet turned to the analysis of the relationship between ethnic psychology and intra-ethnic communication. Alexander Potebnya based his philosophical research on linguistic problems of communication. Mikhail Bakhtin considered the problems of communication within the framework of the cultural model of communication, and Yuri Lotman expounded a semiotic model of communication.

The article Democracy at the Crossroads by the remarkable representative of Russian legal positivism Novgorodtsev (1991) has methodological significance. The author connects the development of democratic society with the high spirituality and the moral education of the population. Only if most of the population is spiritually and morally prepared to effect rights and freedoms realized in the sphere of relations between people, there can be a basis for democratic transformations.

Modern philosophical aspects of the communication studies are well known from the works of Alexei Leontiev, Lyudmila Buyeva, Mikhail Kagan, Yuri Prilyuk, Elizaveta Savrutskaya, Elena Kuznetsova, Dmitri Gavra, Olga Gnatyuk and other representatives of the Moscow, Saint Petersburg, Voronezh, Nizhny Novgorod schools of communication science.

The historically unique multicultural communicative space of Russia and the picture of spiritual and moral values of the country's population make it particularly important to study the problem of communicative practices in the context of the contemporary state of globalization and information communication technologies. On the one hand, such studies stem 
from the need to preserve the uniqueness of the Russian historical and cultural tradition that had evolved for centuries under the conditions of the multi-ethnic, poly-confessional, and multilingual society. On the other hand, it is urgent to consider the peculiarities of the "new digital age' (as Eric Schmidt and Jared Cohen styled it) and to expand the problematic field of clip culture and new metalanguages of culture that have a multifaceted influence on the transformation of communication processes.

The difficulty of studying the latter, involving systematization and theoretical generalization of their features, can be explained by two reasons. First, the speed of social processes and the shortening of innovation cycles (DECREE, 2016). Secondly, too little time has passed since the information communication technologies were introduced into the practice of social development, to generate a system of knowledge about the features of new communication practices and their impact on the psyche and the value orientations of people in the post-globalization era. Consequently, so far it has been hardly possible to develop novel socio-cultural codes of regulation of the communicative practices, recently formed in the mixed objective-virtual reality.

Moreover, recent globalization trends, new information communication technologies, and multivarious temptations of the material environment in the communicative space of modern civilization exacerbate the issue of choosing a line of conduct and forming the range of value attitudes and motivations. At the same time, social ties between people are increasingly acquiring an unstable, short-term character, and the systems of culture codes that have reliably preserved stable features of the national and ethnic cultures for centuries, are suffering a significant transformation.

The globalization processes and new information communication technologies during aggravating international situation have made their adjustments to the transformation of the systems of culture codes. Many codes (traditions, customs, rituals, games, etc.) are gradually losing their defining role as social mechanisms of ensuring the spiritual and moral continuity and preserving the national identity in the ethno-cultural worldview. In the new cultural and communicative reality, linguistic and symbolic models replace the previously established and largely stereotyped traditional standards of everyday life and the norms of communication. In the context of the widespread dissemination of instrumental mass culture models, the unification of methods of managing cultural codes intensifies the erosion of the standards and features of ethnic cultures. It minimizes the chance of historical and cultural inheriting of cultural defining characteristics. As a result of these processes, the ethno-cultural space of ethnic groups crumbles, and the system of social mechanisms, consolidating and reproducing 
the social experience of generations, mutilates. All this creates a crisis of socio-cultural continuity and ethno-cultural identity.

Analysing the communicative and cultural dimensions of city development through branding, Shi-xu (2015) emphasizes the need to proceed from a holistic communicative-cultural approach, which can prevent the destruction of the ethno-cultural spaces of communities.

In the article Arabisation, Globalisation, and Hebraisation Reflexes in Shop Names in the Palestinian Arab Linguistic Landscape in Israel Amara (2018) expresses apprehension about the negative impact of modern unifying processes of a global nature on the local traditional culture, noting that 'Palestinian Arabs work on maintaining their Palestinian-Arab identity in the conflict-ridden Israeli reality.'

In the system of culture codes that have performed informational, communicative, and educational functions, maintained the socio-cultural continuity, and have reproduced the ethnocultural identity, the load falls more and more on language. As the role of language in ensuring the integrity and stability of the cultural and communicative space of ethnic groups increases, the problems of language enter the political field. They are acquiring a dimension of linguistic security in the general national security paradigm.

The peculiar connection between language and culture, and language and social processes lies in the fact that changes in the material environment, in the spiritual and moral relations, and in various forms of communicative action are happening faster than changes in language. Such 'linguistic lag' may have both benefits and drawbacks, although the latter are especially noticeable in modern conditions. The positive aspect of linguistic conservatism is the linguistic stability that contributes to the preservation of the standard of speech and the specific nature of ethnolinguistic tradition. This is undeniably important for any ethnic group seeking to preserve its culture and to maintain the moral basis for the regulation of communicative practices in the world imbalanced by globalization (BESNIER, 2013).

The stability of meanings in linguistic models perpetuate their moral component, which regulates the communication processes. Tracing the historical paths of ethno-cultural and normative-behavioural development, Whorf (1939) noted that behavioural norms and language models coexist synchronously, exerting mutual influence, primarily on the motivation and the value orientations of the people. However, as Whorf emphasized, in language the freedom of choice is restricted, while in the behavioural norm, the elements of situationality and relativism are more expressed. Hence it can be the stability of linguistic models that contributes to the preservation of the historical and cultural experience of an ethnos and forms the foundation of 
its historical memory. In our opinion, this determines the role of language in the formation of the national character and mentality of the people.

In her research on multilingualism Rydell (2018) comes to the conclusion that the most successful in achieving the communicative competence were adult migrants who proceeded from their knowledge of emotional assessments, cultural values and irrational elements of the language, and this knowledge allowed them to more firmly learn the strategies of achieving mutual understanding and agreement in interaction with native speakers. This testifies to the important role of language in preserving the meanings of national culture. Makihara (2013) describes communicative competence as generated and organized socially in socialization practices.

The indissoluble unity of real historical events with their reflection and retention in the ethno-linguistic worldview shape the spirit of the people and the moral component in the regulation of communication. The history of the people embodied in word is its culture and its history proper (KOZHINOV, 2001).

In their research Zones of Interculturality and Linguistic Identity: Tales of Ladino by Sephardic Jews in Bulgaria Davcheva and Fey (2014) note that it was the language that allowed and still allows Sephardic Jews to preserve their complex identity against the backdrop of changing political and social realities.

Acting as a communication asset and linking the present to the past and to the future, language evolves yet retains meanings, i.e., the spiritual content that ensures the impact of the past on the present. It is for this reason that language preserves the world of culture, thereby creating the basis of historical memory and the possibilities of its preservation. The historical memory, imprinted in the language, provides a connection between the past and the future through the present. This reveals the historicism of speech culture, which, being a special form of sociality and a mechanism for preserving historical and cultural meanings, remains the most important means of ensuring the connection of times (BONDYREVA; SAVRUTSKAYA; USTINKIN, 2019).

The Russian language acts as a culture code and a mechanism for preserving the historical and cultural traditions of the millennia-old multinational Russian state bordering between the West and the East. The above features of language provide opportunities for the preservation and reproduction of Russian civilization (ZHIGALEV; SAVRUTSKAYA, 2013).

In this regard, it should be noted that in the contemporary conditions of the development of Russian civilization, the analysis and forecasting of further transformations of the communication processes and the linguistic worldview are inextricably linked with the study 
of the possibilities of preserving the purity of the Russian language as the official language and the language of international communication (RUSSIA, 2005).

The variety of communication processes, stemming from the needs of economic and socio-cultural development and generated by everyday life, translate to the modern vocabulary of the Russian language. Numerous borrowings, both objectively necessary and accidental, introduced into the sphere of the media space and everyday communication, on the one hand, contribute to the enrichment of Russian vocabulary but, on the other hand, pose a significant danger to the preservation of the national culture since they wash away the foundations of speech culture and, consequently, the ethnic mentality. It is obvious that the real practice of the struggle for the preservation of the integrity and culture of the linguistic field of the modern communicative space point to the significance of language as a communicative code that ensures the self-reproduction of society and the historical and cultural continuity on the traditional spiritual and moral foundations. In this regard, we consider language as a means and condition for ensuring the stability of communication processes and consolidating the moral normativity. The ethno-cultural individuality is locked into family and group relations where communication is oriented towards understanding, dialogue and cultural factors. The ways of preserving such individuality are determined by the degree of stability of linguistic norms and habits, thanks to which language becomes one of the most important means of consolidating and translating social experience (SAVRUTSKAYA; NIKITIN; SEMENOV, 2014).

\section{Conclusion}

Thus, the need to address the problems of language in the context of the modern communicative situation and new conditions of civilizational development can be explained by the following circumstances:

Firstly, in conditions when the traditional forms of collectivity and cultural regulation that unite people are destroyed, language becomes one of the most important means of sociocultural continuity and ethno-cultural identity.

Secondly, being a form of expression of intersubjective experience, the linguistic reality produces a new type of communicative behaviour, increasingly acquiring the character of network interaction, entailing new forms of coordination of human behaviour, and offering new mechanisms for managing the communication processes. 
Thirdly, as a sign system formed in the course of the historical and cultural development of peoples, language expresses the generalized experience of generations and ensures the sociocultural continuity, preserving and reproducing specific features of the national cultures.

\section{REFERENCES}

ABUARQOUB, I. A. S. Language barriers to effective communication. Utopía y Praxis Latinoamericana, v. 24, n. 6, p. 64-77, 2019.

ABUARQOUB, I. A. S.; ALSERHAN, F. A. Non-Verbal barriers to effective intercultural communication. Utopía y Praxis Latinoamericana, v. 24, n. 5, p. 307-316. 2019.

AMARA, M. Arabisation, globalisation, and Hebraisation reflexes in shop names in the Palestinian Arab linguistic landscape in Israel. Language and Intercultural Communication, v. 19, n. 3, p. 272-288, 2018.

APEL, K. O. Transformation of philosophy. The a priori of the communication community. Suhrkamp, Frankfurt am Main, 1976. v. 2.

BESNIER, N. Language on the edge of the global: Communicative competence, agency, and the complexity of the local. Language \& Communication, v. 33, n. 4A, p. 463-471, 2013.

BONDYREVA, S. K.; SAVRUTSKAYA, E. P.; USTINKIN, S. V. Ecology of language in problematic field of modern globalization processes. Vlast, v. 27, n. 2, p. 66-73, 2019.

DAVCHEVA, L.; FEY, R. Zones of interculturality and linguistic identity: Tales of Ladino by Sephardic Jews in Bulgaria. Language and Intercultural Communication, v. 14, n. 1, p. 24-40, 2014.

HABERMAS, J. Moral consciousness and communicative action. Russian edition, edited by D. V. Sklyadnev. Nauka. Saint Petersburg, 2000.

KOZHINOV, V. V. History of rus and russian word. An Experience of Unbiased Research. EKSMO-Press, Moscow, 2001.

MAKEYEV, S. N. Phenomenon of social communication in the space of expanded objective-virtual reality. Abstract of Candidate Dissertation, Lobachevsky State University of Nizhny Novgorod, 2017.

MAKIHARA, M. Language, competence, use, ideology, and community on Rapa Nui. Language \& Communication, v. 33, n. 4A, p. 439-449, 2013.

NOVGORODTSEV, P. I. Democracy at the crossroads. In: On the social ideal. Moscow: Pressa, 1991. pp. 540-549.

RUSSIA. Decree of the President of the Russian Federation of 1 December 2016 No. 642. On the Strategy of Scientific and Technological Development of the Russian Federation, Section II, Clause 16a. 2016. 
RUSSIA. Federal Law of 1 June 2005 No. 53-FZ 'On the State Language of the Russian Federation. 2005.

RYDELL, M. Being 'a competent language user' in a world of Others - Adult migrants' perceptions and constructions of communicative competence. Linguistics and Education, v. 45, p. 101-109, 2018.

SAVRUTSKAYA, E. P.; NIKITIN, A. V.; SEMENOV, D. V. The role of language in the formation of national images of the world. In: INTERNATIONAL MULTIDISCIPLINARY SCIENTIFIC CONFERENCE ON SOCIAL SCIENCES AND ARTS: ANTHROPOLOGY, ARCHAEOLOGY, HISTORY AND PHILOSOPHY, 2014, Varna. Proceedings [...]. Varna, Bulgaria, Sep. 2014, p. 881-886.

SHI-XU. International city branding as intercultural discourse: workplace, development, and globalization. Language and Intercultural Communication, v. 15, n. 1, p. 161-178, 2015.

UMBAR, K. Concept of language politeness and building character education. Utopía y Praxis Latinoamericana, v. 24, n. 5, p. 379-390, 2019.

WHORF, B. The relation of habitual thought and behaviour to language. 1939. Available: https://www.generalsemantics.org/wp-content/uploads/2011/05/articles/etc/1-4-whorf.pdf. Access: 10 Sep. 2020.

ZHIGALEV, B. A.; SAVRUTSKAYA, E. P. Language in the field of education nowadays. Research Bulletin Sworld: Modern Scientific Research and Their Practical Application, J21315-020, 2013.

\section{How to reference this article}

BONDYREVA, S. K.; NIKITIN, A. V.; SAVRUTSKAYA, E. P.; USTINKIN, S. V. Problematic field of communicative practices under globalization: linguistic aspect. Rev. EntreLínguas, Araraquara, v. 7, n. esp. 2, e021029, 2021. e-ISSN: 2447-3529. DOI: https://doi.org/10.29051/el.v7iesp.2.15155

Submitted: 05/01/2021

Required revisions: 26/02/2021

Approved: 24/03/2021

Published: 01/06/2021 